\title{
ADOLESCENTS' PERSONAL AUTONOMY AND INTENTIONS ON DENTAL AND ORAL HEALTH MAINTENANCE BEHAVIOR
}

Nita Sofia Rakhmawati*, Irwan Budiono ${ }^{\star *}$, Eunike Raffy Rustiana ${ }^{* * *}$, Ani Subekti ${ }^{\star \star * *}$

*Program Studi Ilmu Kesehatan Masyarakat, Pascasarjana Universitas Negeri Semarang

**Jurusan IImu Kesehatan Masyarakat, Universitas Negeri Semarang

***Jurusan Ilmu Kesehatan Masyarakat, Universitas Negeri Semarang

****Jurusan Kesehatan Gigi, Poltekkes Kemenkes Semarang

Correspondence: rakhmawati.ns@students.unnes.ac.id

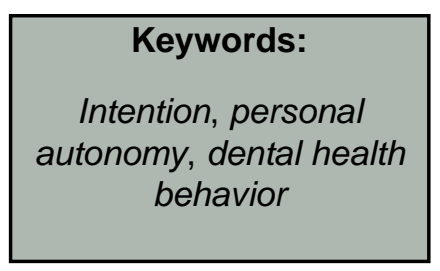

\begin{abstract}
Background: Oral health problems are behavioral problems. One of the groups prone to dental and mouth problems is teenagers. The purpose of this study was to analyze the relationship between intention and personal autonomy with the behavior of maintaining oral health in adolescents.

Method: This study was an analytic survey study with a cross sectional study approach. The subjects of this study were teenagers at Texmaco Semarang Vocational School, totaling 90 students with a total sampling technique. The research instrument used was a questionnaire. Data analysis was carried out by univariate analysis (frequency distribution) to explain the characteristics and results of each variable and bivariate analysis using the Spearman rank correlation test to see the relationship between the two variables.

Result: The results of the study show female respondents have a higher intention/motivation in maintaining dental health compared to male respondents. Female respondents tend to prefer to decide for themselves in relation to dental health care compared to male respondents. Female respondents are better at maintaining dental health, compared to male respondents. Intention and personal autonomy are related to adolescent actions in maintaining dental and oral health with p-value $0.000<0.05$.

Conclusion: Behavior has an important role in public health status. Intention as a major predictor of behavior. Personal autonomy contributes greatly to behavior change.
\end{abstract}

\section{PENDAHULUAN}

Kesehatan gigi dan mulut adalah salah satu aspek kesehatan yang sangat penting karena dapat mengganggu kesehatan tubuh lainnya. ${ }^{1}$ Pada masyarakat Indonesia kesehatan gigi dan mulut belum menjadi prioritas dan belum menjadi alasan penting masyarakat untuk memperoleh pelayanan kesehatan. ${ }^{2}$ Terjadi kenaikan proporsi masalah gigi dan mulut pada penduduk Indonesia dimana sebanyak 57,6\% (tahun 2018) penduduk indonesia bermasalah gigi dan mulutnya. Angka tersebut lebih tinggi dibandingkan pada tahun 2013 yang mencatat sebanyak $53,3 \%$ penduduk bermasalah gigi dan mulutnya. ${ }^{3}$ Salah satu faktor risiko penyebab tingginya masalah gigi dan mulut yaitu buruknya perilaku dalam menjaga kesehatan gigi dan mulut. ${ }^{4}$ Diketahui proporsi perilaku menyikat gigi dengan benar hanya dilakukan sebesar 2,8\% penduduk Indonesia. ${ }^{5}$ Riskesdas tahun 2018 mengidentifikasi salah satu kelompok rentan terhadap masalah gigi dan mulut yaitu penduduk usia 10-14 tahun dimana 55,6\% menderita penyakit gigi dan mulut, dan penduduk usia 15-24 tahun sebesar $51,9 \%$ menderita penyakit gigi dan mulut. Usia tersebut tergolong dalam usia remaja. 
Diketahui pula bahwa perilaku pemeliharaan kesehatan gigi dan mulut masih rendah. ${ }^{6}$

Perilaku merupakan suatu tanggapan atau reaksi individu terhadap rangsangan atau lingkungan. ${ }^{7}$ Pada usia remaja masalah kesehatan gigi dan mulut akan berdampak pada kualitas hidup yang berkelanjutan. Semakin baik status kesehatan gigi dan mulut remaja maka kualitas hidup akan semakin baik dan sebaliknya status kesehatan gigi dan mulut yang buruk akan mempengaruhi kualitas hidup yang rendah. ${ }^{8}$ Di Kota Semarang kesehatan gigi dan mulut masih menjadi suatu persoalan kesehatan yang memelukan upaya penanggulangan. Terdapat dua permasalahan paling dominan pada anak usia sekolah dan remaja yaitu salah satunya karies gigi. Perlu adanya peningkatan pelayanan kesehatan gigi dan mulut khususnya pada upaya kesehatan secara promotif dan preventif. 9

Masalah kesehatan gigi dan mulut juga terjadi pada siswa SMU/MA binaan Puskesmas Mangkang Semarang. Data penjaringan kesehatan gigi Puskesmas Mangkang tahun 2019 diperoleh masih terdapat banyak siswa dengan kondisi kesehatan gigi dan mulut yang buruk. Salah satunya SMK Texmaco dengan proporsi masalah gigi yang tinggi dimana $50 \%$ siswa masih menderita masalah gigi yaitu gigi berlubang maupun penyakit mulut lainnya. Kondisi tersebut paling banyak diderita oleh siswa kelas sepuluh (X). Sebagian besar siswa masih memiliki kebiasaan menggosok gigi dengan waktu yang tidak tepat yaitu pada saat mandi, masih banyak siswa dengan konsumsi makanan manis dan lengket serta masih banyak siswa enggan memeriksakan gigi ke dokter gigi.

Perlu dikaji lebih lanjut terkait faktor-faktor yang dapat mempengaruhi perilaku kesehatan, baik faktor internal maupun faktor eksternal. Beberapa penelitian menyebutkan bahwa perilaku dipengaruhi oleh niat seseorang untuk bertindak, sehubungan dengan kesehatan atau perawatan kesehatannya (behaviour intention) dan kemampuan individu untuk bertindak sesuai dengan keinginannya tanpa ada paksaan (personal autonomy). ${ }^{10}$ Niat berperilaku dapat memprediksi tentang kecenderungan seseorang untuk melakukan atau tidak melakukan perilaku tertentu. Semakin keras niat seseorang untuk berperilaku maka semakin besar pula kecenderungannya untuk benar-benar mewujudkan perilaku tersebut. ${ }^{11}$ Personal autonomy berkaitan dengan pengambilan keputusan atau tindakan seseorang. Otonomi pribadi berkontribusi besar dalam perubahan perilaku. ${ }^{12}$ Berdasarkan penjabaran teori dan beberapa hasil penelitian di atas, dalam penelitian ini akan dikaji kaitannya dengan niat dan otonomi pribadi terhadap perilaku pemeliharaan kesehatan gigi. Subyek penelitian adalah remaja dan akan diidentifikasi niat dan otonomi pribadi berdasarkan karakteristik jenis kelamin, agar diketahui kecenderungan niat antara remaja laki-laki dan perempuan dan otonomi pribadi antara remaja lakilaki dan perempuan.

\section{METODE PENELITIAN}

Penelitian ini merupakan penelitian survei analitik dengan pendekatan cross sectional studi. Penelitian telah dilaksanakan pada bulan April 2021 dan telah mendapatkan keterangan kelaikan etik dari Komisi Etik Penelitian Kesehatan (KEPK) Universitas Negeri Semarang No. 045/KEPK/EC/2021. Subyek penelitian yang digunakan yaitu siswa kelas X SMK Texmaco Semarang yang berjumlah 90 siswa dengan teknik pengambilan sampel total sampling. Adapun kriteria inklusi yang digunakan adalah merupakan siswa kelas $\mathrm{X}$ SMK Texmaco, dimana dengan masalah rongga mulut yang tinggi, bersedia menjadi responden penelitian, kooperatif dan mampu mengikuti penelitian sesuai prosedur yang 
telah ditentukan. Kriteria ekslusi yang digunakan adalah siswa kelas $X$ SMK Texmaco yang pada saat penelitian tidak berada di tempat dan tidak bersedia menjadi responden penelitian.

Variabel independen dalam penelitian ini yang pertama adalah niat yang diukur berdasarkan tiga indikator yaitu attitude toward the behavior, subjective norm dan perceived behavioral control. Variabel independen kedua adalah otonomi pribadi yang diukur berdasarkan dua indikator yaitu berdasarkan aspek psikologis dan aspek faktor sosial. Variabel dependent penelitian ini adalah perilaku pemeliharaan kesehatan gigi dan mulut yaitu perilaku individu terkait kebiasaan menyikat gigi (waktu, frekuensi, cara), pemilihan dan penggunaan sikat gigi, penggunaan pasta gigi, pengaturan pola makan (kariogenik, non kariogenik, frekuensi) dan kebiasaan periksa gigi rutin.

Pengambilan data dilakukan dengan instrumen kuesioner dengan skala likert dibagikan dan diisi oleh siswa. Kuesioner telah dinyatakan valid dan reliabel dimana hasil pengujian diperoleh nilai $p$-value $<0.05$ dan cronbach's alpha $>0.60$. Uji validitas dilakukan pada 40 siswa SMA Bina Nusantara Semarang yang memiliki karakteristik hampir sama dengan subyek penelitian. Kuesioner niat terdiri dari 11 item pernyataan, kuesioner otonomi pribadi terdiri dari 8 item pernyataan dan kuesioner perilaku pemeliharaan kesehatan gigi dan mulut terdiri dari 16 item pernyataan. Pernyataan dalam bentuk favorable dan unfavorable. Analisa data dilakukan dengan analisis univariat (distribusi frekuensi) untuk menjelaskan karakteristik dan hasil dari masingmasing variabel dan analisis bivariat dengan uji spearman rank correlation untuk melihat adanya hubungan antara dua variabel. Dijelaskan pula deskripsi niat berdasarkan aspek karakteristik jenis kelamin responden, otonomi pribadi berdasarkan karakteristik jenis kelamin responden dan perilaku pemeliharaan kesehatan gigi dan mulut berdasarkan karakteristik jenis kelamin responden.

\section{HASIL PENELITIAN}

Disajikan Tabel 1 karakteristik responden penelitian yang terdiri dari jenis kelamin dan umur sebagai berikut:

Tabel 1. Karakteristik Subyek Penelitian

\begin{tabular}{lcc}
\hline $\begin{array}{l}\text { Karakteristik } \\
\text { Responden }\end{array}$ & Jumlah & Persentase \\
\hline Jenis kelamin & & \\
Laki-laki & 43 & 47.8 \\
Perempuan & 47 & 52.2 \\
Total & 90 & 100 \\
\hline Umur & & \\
16 tahun & 37 & 41,1 \\
17 tahun & 42 & 46.7 \\
18 tahun & 11 & 12,2 \\
Total & 90 & 100 \\
\hline \multicolumn{1}{l}{ Tabel 1 menunjukkan responden dalam }
\end{tabular}

penelitian ini terdiri dari 47 (52\%) dengan jenis kelamin laki-laki dan $43(48 \%)$ dengan jenis kelamin perempuan. Dilihat dari karakteristik umur subyek didominasi dalam umur 17 tahun yaitu 42 (47\%) responden. Semua responden termasuk dalam kelas X SMU/MA kategori remaja.

Tabel 2. Distribusi Frekuensi Variabel Penelitian

\begin{tabular}{|c|c|c|}
\hline Variabel & Jumlah & Persentase \\
\hline \multicolumn{3}{|l|}{ Niat } \\
\hline Tinggi & 8 & 8.9 \\
\hline Sedang & 71 & 78.9 \\
\hline Rendah & 11 & 12.2 \\
\hline Total & 90 & 100 \\
\hline \multicolumn{3}{|l|}{$\begin{array}{l}\text { Otonomi } \\
\text { pribadi }\end{array}$} \\
\hline Tinggi & 15 & 16.7 \\
\hline Sedang & 66 & 73.3 \\
\hline Rendah & 9 & 10.0 \\
\hline Total & 90 & 100 \\
\hline \multicolumn{3}{|l|}{ Tindakan } \\
\hline Baik & 11 & 12.2 \\
\hline Sedang & 67 & 74.4 \\
\hline Rendah & 12 & 13.3 \\
\hline Total & 90 & 100 \\
\hline \multicolumn{3}{|c|}{ Berdasarkan Tabel 2 diketahui } \\
\hline
\end{tabular}


tindakan pemeliharaan kesehatan gigi kategori sedang sebanyak 67 (75\%) siswa. Hal tersebut dapat diartikan belum semua aspek pemeliharaan kesehatan gigi dilakukan oleh siswa, belum semua siswa mengambil keputusan (otonomi pribadi) terhadap tindakan yang dilakukan atas dasar kemauan sendiri serta belum semua siswa berniat/termotivasi bertindak sehubungan dengan kesehatan atau perawatan kesehatannya.

Tabel 3 menunjukkan apabila dilihat dari karakteristik jenis kelamin, responden perempuan lebih memiliki niat/motivasi yang tinggi dalam pemeliharaan kesehatan gigi yaitu 7 (7.8\%), dibandingkan dengan responden laki-laki hanya 1 (1.1\%). Responden perempuan cenderung lebih memiliki keinginan yang kuat dibandingkan dengan responden laki-laki. Tidak ada responden dengan niat yang rendah yaitu $0(0 \%)$, sedangkan terdapat 11 (12.2\%) responden laki-laki dengan niat/kemauan yang rendah.

Tabel 4 menunjukkan bahwa, apabila dilihat dari karakteristik jenis kelamin, responden perempuan lebih memiliki otonomi pribadi yang tinggi dalam pemeliharaan kesehatan gigi yaitu 12 (13.3\%), dibandingkan dengan responden laki-laki hanya 3 (3.3\%). Responden perempuan cenderung lebih memilih memutuskan sendiri kaitannya dengan pemeliharaan kesehatan gigi dibandingkan dengan responden laki-laki.

Tabel 5 menunjukkan tindakan pemeliharaan kesehatan gigi pada responden laki-

laki lebih rendah yaitu hanya $2(2.2 \%)$ responden dengan kategori baik, dibandingkan dengan reponden perempuan yang sudah sebanyak 9 $(10.0 \%)$ responden dengan perilaku kategori baik. Sebanyak $10(11.1 \%)$ responden laki-laki dengan perilaku/tindakan yang rendah, dan pada responden perempuan hanya $2(2.2 \%)$ responden dengan perilaku kategori yang rendah. Responden perempuan lebih baik dalam pemeliharaan kesehatan gigi, dibandingkan dengan responden laki-laki.

Tabel 3. Niat ditinjau dari Karakteristik Jenis Kelamin

\begin{tabular}{lcccccccc}
\hline \multirow{2}{*}{ Variabel } & \multicolumn{9}{c}{ Niat } \\
\cline { 2 - 9 } & \multicolumn{2}{c}{ Rendah } & \multicolumn{2}{c}{ Sedang } & \multicolumn{2}{c}{ Tinggi } & \multicolumn{3}{c}{ Total } \\
\cline { 2 - 9 } & $\mathrm{N}$ & $\%$ & $\mathrm{~N}$ & $\%$ & $\mathrm{~N}$ & $\%$ & $\mathrm{~N}$ & $\%$ \\
\hline Jenis Kelamin & & & & & & & & \\
Laki-laki & 11 & 12.2 & 31 & 34.4 & 1 & 1.1 & 43 & 47.8 \\
Perempuan & 0 & 0 & 40 & 44.4 & 7 & 7.8 & 47 & 52.2 \\
Total & 11 & 12.2 & 71 & 78.9 & 8 & 8.9 & 90 & 100 \\
\hline
\end{tabular}

Tabel 4. Otonomi Pribadi ditinjau dari Karakteristik Jenis Kelamin

\begin{tabular}{lcccccccc}
\hline \multirow{2}{*}{ Variabel } & \multicolumn{8}{c}{ Otonomi Pribadi } \\
\cline { 2 - 9 } & \multicolumn{2}{c}{ Rendah } & \multicolumn{2}{c}{ Sedang } & \multicolumn{2}{c}{ Tinggi } & \multicolumn{2}{c}{ Total } \\
\cline { 2 - 9 } & $\mathrm{N}$ & $\%$ & $\mathrm{~N}$ & $\%$ & $\mathrm{~N}$ & $\%$ & $\mathrm{~N}$ & $\%$ \\
\hline Jenis Kelamin & & & & & & & & \\
Laki-laki & 5 & 5.6 & 35 & 38.9 & 3 & 3.3 & 43 & 47.8 \\
Perempuan & 4 & 4.4 & 31 & 34.4 & 12 & 13.3 & 47 & 52.2 \\
Total & 9 & 10.0 & 66 & 73.3 & 15 & 16.7 & 90 & 100 \\
\hline
\end{tabular}


Tabel 5. Perilaku Pemeliharaan Kesehatan Gigi ditinjau dari Karakteristik Jenis Kelamin

\begin{tabular}{lcccccccc}
\hline \multirow{2}{*}{ Variabel } & \multicolumn{8}{c}{ Tindakan pemeliharaan kesehatan gigi } \\
\cline { 2 - 10 } & \multicolumn{2}{c}{ Rendah } & \multicolumn{2}{c}{ Sedang } & \multicolumn{3}{c}{ Baik } & \multicolumn{2}{c}{ Total } \\
\cline { 2 - 9 } & $\mathrm{N}$ & $\%$ & $\mathrm{~N}$ & $\%$ & $\mathrm{~N}$ & $\%$ & $\mathrm{~N}$ & $\%$ \\
\hline Jenis Kelamin & & & & & & & & \\
Laki-laki & 10 & 11.1 & 31 & 34.4 & 2 & 2.2 & 43 & 47.8 \\
Perempuan & 2 & 2.2 & 36 & 40.0 & 9 & 10.0 & 47 & 52.2 \\
Total & 12 & 13.3 & 67 & 74.4 & 11 & 12.2 & 90 & 100 \\
\hline
\end{tabular}

Tabel 6. Hasil Uji Spearman Rank Correlation

\begin{tabular}{|c|c|c|c|c|c|c|c|c|c|}
\hline \multirow[t]{3}{*}{ Variabel } & \multicolumn{8}{|c|}{ Tindakan pemeliharaan kesehatan gigi } & \multirow[t]{3}{*}{$p$-value } \\
\hline & \multicolumn{2}{|c|}{ Baik } & \multicolumn{2}{|c|}{ Sedang } & \multicolumn{2}{|c|}{ Rendah } & \multicolumn{2}{|c|}{ Total } & \\
\hline & $\mathrm{N}$ & $\%$ & $\mathrm{~N}$ & $\%$ & $\mathrm{~N}$ & $\%$ & $\mathrm{~N}$ & $\%$ & \\
\hline \multicolumn{10}{|l|}{ Niat } \\
\hline Tinggi & 5 & 5.6 & 3 & 3.3 & 0 & 0 & 8 & 8.9 & 0.000 \\
\hline Sedang & 6 & 6.7 & 57 & 63.3 & 8 & 8.9 & 71 & 78.9 & \\
\hline Rendah & 0 & 0 & 7 & 7.8 & 4 & 4.4 & 11 & 12.2 & \\
\hline Total & 11 & 12.2 & 67 & 74.4 & 12 & 13.3 & 90 & 100 & \\
\hline \multicolumn{10}{|l|}{$\begin{array}{l}\text { Otonomi } \\
\text { pribadi }\end{array}$} \\
\hline Tinggi & 11 & 12.2 & 4 & 4.4 & 0 & 0 & 15 & 16.7 & 0.000 \\
\hline Sedang & 0 & 0 & 57 & 63.3 & 9 & 10.0 & 66 & 73.3 & \\
\hline Rendah & 0 & 0 & 6 & 6.7 & 3 & 3.3 & 9 & 10.0 & \\
\hline Total & 11 & 12.2 & 67 & 74.4 & 12 & 13.3 & 90 & 100 & \\
\hline
\end{tabular}

Tabel 6 hasil uji statistik diperoleh nilai $p$ value $<0.05$ baik untuk aspek niat maupun otonomi pribadi terhadap tindakan pemeliharaan kesehatan gigi dan mulut. Hal tersebut dapat diartikan bahwa niat dan otonomi pribadi berhubungan dengan tindakan remaja dalam memelihara kesehatan gigi dan mulutnya. Semakin tinggi niat yang dimiliki maka akan berpengaruh terhadap kemauan bertindak remaja dalam memelihara kesehatan gigi, dan sebaliknya semakin rendah niat yang ada maka akan berpengaruh terhadap tindakan pemeliharaan kesehatan gigi dan mulut yang rendah. Otonomi pribadi/pengambilan keputusan dengan kesadaran diri tanpa adanya paksaan akan mempengaruhi terhadap kemauan melakukan tindakan kaitannya dengan pemeliharaan kesehatan gigi, sebaliknya pengambilan keputusan dengan adanya paksaan maka akan berpengaruh negatif terhadap remaja dalam melakukan pemeliharaan kesehatan gigi.

\section{DISKUSI}

Hasil penelitian menunjukkan niat/kemauan untuk bertindak sehubungan dengan kesehatan atau perawatan kesehatan paling banyak dimiliki oleh responden perempuan. Responden perempuan cenderung lebih memiliki keinginan yang kuat dibandingkan dengan responden laki-laki dalam memelihara kesehatan gigi dan mulutnya. Apabila dilihat dari perilaku/tindakan pemeliharaan kesehatan gigi, perempuan lebih baik pula dalam memelihara kesehatan gigi dan mulutnya dibandingkan dengan responden laki-laki. Hal tersebut berbanding lurus, dimana niat yang tinggi akan berkontribusi terhadap tindakan memelihara kesehatan gigi yang baik, dan hal tersebut lebih banyak dimiliki oleh responden perempuan dibandingkan dengan responden laki-laki.

Secara umum niat dianggap menjadi faktor penting bagi siswa yang menentukan siswa 
melangkah, membuat siswa tetap melangkah, dan menentukan ke mana siswa mencoba melangkah. ${ }^{13}$ Lebih lanjut dijelaskan bahwa niat adalah sesuatu yang menghidupkan (energize), mengarahkan, dan mempertahankan perilaku sehingga membuat siswa bergerak, menempatkan siswa dalam suatu arah tertentu, dan menjaga siswa agar terus bergerak kaitannya dengan pemeliharaan kesehatan. Secara tidak langsung niat akan berpengaruh terhadap sikap dan tindakan yang akan dilakukan. ${ }^{14}$ Beberapa penelitian mengungkapkan bahwa laki-laki dan perempuan memiliki karakteristik bawaan yang berbeda. Perempuan cenderung menggunakan perasaan dan lebih mampu meningkatkan kesadaran dirinya untuk memotivasi diri dalam melakukan suatu tindakan dibandingkan dengan laki-laki. ${ }^{15}$ Perempuan lebih memperhatikan penampilan dirinya dibandingkan dengan laki-laki yang acuh terhadap penampilan sehingga kemauannya/niat yang dimiliki cenderung pasif dan tidak mendukung tindakannya. ${ }^{16}$ Penelitian membuktikan bahwa perempuan lebih mampu merawat kesehatan giginya dibandingkan dengan laki-laki. Masalah kesehatan gigi pada laki-laki lebih tinggi dibandingkan dengan perempuan. ${ }^{17}$ Perilaku pemeliharaan kesehatan gigi dan mulut lebih tinggi pada perempuan dibandingkan pada responden laki-laki. ${ }^{18}$

Selanjutnya, hasil penelitian menunjukkan otonomi pribadi cenderung lebih tinggi pada responden perempuan dibandingkan dengan responden laki-laki. Responden perempuan cenderung lebih memilih memutuskan sendiri kaitannya dengan pemeliharaan kesehatan gigi dibandingkan dengan responden laki-laki. Secara umum otonomi pribadi merujuk pada pengambilan keputusan untuk bertindak sesuai dengan keinginannya tanpa adanya suatu paksaan. ${ }^{19}$ Disebutkan semakin tinggi tingkat partisipasi individu dalam proses pengambilan keputusan, maka akan memberi pengaruh yang positif terhadap tindakan yang akan dilakukan kaitannya dengan pemeliharaan kesehatan. ${ }^{20}$ Pada penelitian ini dapat diketahui bahwa pada responden perempuan, mereka lebih aktif dan lebih menentukan sendiri terhadap suatu yang diingikan, responden perempuan lebih mandiri dan lebih aktif dalam menentukan tindakan sehingga dilihat dari tindakan pemeliharaan kesehatan gigi, perempuan lebih baik dibandingkan dengan laki-laki. Pada responden laki-laki biasanya masih bergantung pada sosok orang tua yaitu ibu, sehingga dalam hal pengambilan keputusan masih melibatkan campur tangan orang tua. Banyak faktor yang mempengaruhi, dan apabila didapati orang tua dengan pengetahuan yang kurang maka dapat berdampak pada pengambilan keputusan yang kurang baik kaitannya dengan pemeliharaan kesehatan. ${ }^{21}$ Remaja perempuan pada umumnya telah mencapai kematangan fisik dan emosional, berbeda dengan laki-laki yang justru baru belajar bagaimana menjadi seorang laki-laki dalam lingkungan sosialnya, sehingga hal tersebut mempengaruhi otonomi pribadi, dimana perempuan lebih mampu dan mandiri dalam pengambilan suatu keputusan dibandingkan dengan laki-laki. ${ }^{22}$

Hasil uji statistik menunjukkan niat berhubungan dengan tindakan pemeliharaan kesehatan gigi dan mulut pada remaja. Semakin tinggi niat yang dimiliki maka akan berpengaruh terhadap kemauan bertindak remaja dalam memelihara kesehatan gigi, dan sebaliknya semakin rendah niat yang ada maka akan berpengaruh terhadap tindakan pemeliharaan kesehatan gigi dan mulut yang rendah. Niat (Behavior intention) merupakan keputusan seseorang untuk melakukan tindakan tertentu/motivasi seseorang untuk melakukan suatu 
perilaku. ${ }^{10}$ Beberapa penelitian membuktikan bahwa behavior intention merupakan representasi kognitif dari kesiapan seseorang untuk melaksanakan perilaku tertentu dan dipandang sebagai anteseden terdekat pada perilaku. ${ }^{23}$ Niat secara akurat dapat memprediksi kesesuaian perilaku. ${ }^{24}$ Niat mencerminkan keinginan individu untuk melakukan suatu perilaku tertentu. Semakin tinggi niat individu melakukan suatu perilaku, maka semakin besar kemungkinan individu menampilkan perilaku tersebut. ${ }^{25}$

Niat memiliki hubungan yang positif dalam mempengaruhi perubahan perilaku. ${ }^{26,27}$ Niat merupakan faktor yang paling utama dalam merubah perilaku. ${ }^{12}$ Niat secara langsung mempengaruhi terjadinya perilaku. Niat berperan secara langsung dalam pembentukan perilaku. ${ }^{28}$ Niat berperilaku dapat memprediksi tentang kecenderungan seseorang untuk melakukan atau tidak melakukan perilaku tertentu. Semakin keras niat seseorang untuk berperilaku maka semakin besar pula kecenderungannya untuk benar-benar mewujudkan perilaku tersebut. ${ }^{29,30}$

Hasil uji statistik menunjukkan otonomi pribadi berhubungan dengan tindakan remaja dalam memelihara kesehatan gigi dan mulutnya. Otonomi pribadi/ pengambilan keputusan dengan kesadaran diri tanpa adanya paksaan akan mempengaruhi terhadap kemauan melakukan tindakan kaitannya dengan pemeliharaan kesehatan gigi, sebaliknya pengambilan keputusan dengan adanya paksaan maka akan berpengaruh negatif terhadap remaja dalam melakukan pemeliharaan kesehatan gigi. Personal autonomy adalah kewenangan berperilaku yang ditentukan berdasarkan keinginan diri sendiri. Personal autonomy berkaitan dengan pengambilan keputusan atau tindakan seseorang. ${ }^{12}$ Otonomi pribadi berkontribusi besar dalam perubahan perilaku. Otonomi pribadi dalam pengambilan keputusan atau tindakan sangat berpengaruh terhadap perilaku. ${ }^{31}$ Otonomi pribadi yang kuat akan mempertahankan tindakan individu dalam melakukan perilaku tertentu. Otonomi pribadi dapat mencegah terjadinya perilaku yang kurang baik terhadap kesehatan. ${ }^{32}$

Otonomi pribadi secara signifikan berhubungan dengan tindakan ibu hamil dalam pencarian pelayanan kesehatan. Otonomi pribadi memiliki peran yang besar dalam pengambilan keputusan untuk melakukan suatu perilaku. ${ }^{33}$ Adanya hubungan antara otonomi pribadi terhadap perubahan perilaku, dimana ketika otonomi tinggi maka perubahan perilaku akan meningkat. ${ }^{12}$

\section{KESIMPULAN}

Responden perempuan lebih memiliki niat/motivasi yang tinggi dalam pemeliharaan kesehatan gigi dibandingkan dengan responden laki-laki. Responden perempuan cenderung lebih memilih memutuskan sendiri kaitannya dengan pemeliharaan kesehatan gigi dibandingkan dengan responden laki-laki. Responden perempuan lebih baik dalam pemeliharaan kesehatan gigi, dibandingkan dengan responden laki-laki. Niat dan otonomi pribadi berhubungan dengan tindakan remaja dalam memelihara kesehatan gigi dan mulutnya. Semakin tinggi niat yang dimiliki maka akan berpengaruh terhadap kemauan bertindak remaja dalam memelihara kesehatan gigi, dan sebaliknya semakin rendah niat yang ada maka akan berpengaruh terhadap tindakan pemeliharaan kesehatan gigi dan mulut yang rendah. Otonomi pribadi/pengambilan keputusan dengan kesadaran diri tanpa adanya paksaan akan mempengaruhi terhadap kemauan melakukan tindakan kaitannya dengan pemeliharaan kesehatan gigi, sebaliknya pengambilan keputusan dengan adanya paksaan maka akan berpengaruh negatif terhadap remaja dalam melakukan pemeliharaan kesehatan gigi. 


\section{UCAPAN TERIMAKASIH}

Penelitian ini didanai oleh DIPA

Pascasarjana Universitas Negeri Semarang pada tahun 2021 (Nomor: 94.19.5/UN37/PPK.5.1/2021).

\section{DAFTAR PUSTAKA}

1. Achmad $\mathrm{H}$, Armedina $\mathrm{RN}$, Timokhina $\mathrm{T}$, Goncharov V V, Sitanaya R, Riyanti E. Literature Review: Problems of Dental and Oral Health Primary School Children. Indian J Forensic Med Toxicol. 2021;15(2):4146-62.

2. Jalias SJFD, Idris FP. Pengaruh mutu pelayanan kesehatan gigi dan mulut terhadap minat kembali pasien melalui tingkat kepuasan di puskesmas tamalate makassar 2020. J Muslim Community Heal. 2020;1(2):37-49.

3. Napitupulu RLY, Adhani R, Erlita I. Hubungan Perilaku Menyikat Gigi, Keasaman Air, Pelayanan Kesehatan Gigi Terhadap Karies Di Man 2 Batola. Dentin J Kedokt Gigi. 2019;III(1):17-22.

4. Subekti A, Sutomo B, Santoso B, Salikun S, Amalia R, Puspita R, et al. Penerapan Media Software Interaktif Sebagai Media Edukasi Dalam Perubahan Tingkat Pengetahuan Dan Perilaku Kesehatan Gigi Serta Tingkat Kebersihan Gigi. Link. 2018;14(1):31.

5. Haryanto $R$, Setiasari $R$, Hastuti EP. Meningkatkan Pengetahuan Cara Menggosok Gigi Dengan Baik Dan Benar Melalui Penyuluhan Pada Anak. J Kreat Pengabdi Kpd Masy. 2021;4(2):393-9.

6. Kementerian Kesehatan Republik Indonesia. Laporan Nasional Riskesdas 2018 [Internet]. 2018. Available from: http://www.yankes.kemkes.go.id/assets/downl oads/PMK No. 57 Tahun 2013 tentang PTRM.pdf

7. Gómez-Polo C, Vilches A-A, Ribas D, Castaño-Séiquer A, Montero J. Behaviour and Anxiety Management of Paediatric Dental Patients through Virtual Reality: A Randomised Clinical Trial. J Clin Med. 2021;10(14):1-13.

8. Yactayo-Alburquerque MT, Alen-Méndez ML, Azañedo D, Comandé D, Hernández-Vásquez A. Impact of oral diseases on oral healthrelated quality of life: A systematic review of studies conducted in Latin America and the Caribbean. PLoS One. 2021;16(6 June):1-23.

9. Nugraheni H, Sadimin, Sukini. Determinan Perilaku Pencegahan Karies Gigi Siswa Sekolah Dasar Di Kota Semarang. J Kesehat Gigi. 2019;6(2):45-50.

10. Ajzen I. The theory of planned behavior: Frequently asked questions. Hum Behav Emerg Technol. 2020;2(4):314-24.
11. Monica BR, Widjanarko B, Prabamurti PN. Hubungan Pengetahuan, Norma Subjektif Dan Persepsi Kontrol Perilaku Dengan Niat Ibu Rumah Tangga Berisiko Hiv Dalam Mengakses Layanan Vct. J Kesehat Masy. 2019;7(4):496-503.

12. Asriningrum S. Korelasi Antara Niat Dukungan Sosial, Informasi Kesehatan, Otonomi Pribadi, Situasi Untuk Bertindak Dalam Merubah Perilaku Perawat Memilah Limbah Medis Di RS Al Islam Bandung. 2019;1(2):99-113.

13. Coman C, Țîru LG, Meseșan-Schmitz L, Stanciu C, Bularca MC. Online teaching and learning in higher education during the coronavirus pandemic: Students' perspective. Sustain. 2020;12(24):1-22.

14. Brahmana R, Brahmana RK, Memarista G. Planned Behaviour in Purchasing Health Insurance. South East Asian J Manag. 2018;12(1):43-64.

15. Christov-moore L, Simpson EA, Grigaityte K, lacoboni M, Ferrari PF, Sciences B, et al. Empathy: Gender effects in brain and behavior. Front Psychol. 2014;46(Pt 4):60427.

16. Denich AU, Ifdil I. Konsep Body Image Remaja Putri. J Konseling dan Pendidik. 2015;3(2):55.

17. Hamasha $\mathrm{AAH}$, Alshehri $A$, Alshubaiki $A$, Alssafi $F$, Alamam H, Alshunaiber R. Genderspecific oral health beliefs and behaviors among adult patients attending King Abdulaziz Medical City in Riyadh. Saudi Dent J [Internet]. 2018;30(3):226-31. Available from: https://doi.org/10.1016/j.sdentj.2018.05.003

18. Mamai-Homata $E$, Koletsi-Kounari $H$, Margaritis V. Gender differences in oral health status and behavior of Greek dental students: A meta-analysis of 1981, 2000, and 2010 data. J Int Soc Prev Community Dent. 2016;6(1):608.

19. Estik Ikka Indah Purwati, Nuryadi YTH. Decision Making in The Refferal Implementation at Public Health Center as First Level Health Facility. e-Jurnal Pustaka Kesehat. 2017;5(2):231-8.

20. Sischo L, Broder HL. Oral health-related quality of life: What, why, how, and future implications. J Dent Res. 2011;90(11):126470.

21. Abdat M, Ramayana I. Relationship between mother's knowledge and behaviour with oral health status of early childhood. Padjadjaran $\mathrm{J}$ Dent. 2020;32(3):166.

22. García-Castilla FJ, Sánchez IM, Campos G, Arroyo Resino D. Impact of Gender and Relationship Status on Young People's Autonomy and Psychological Wellbeing. Front Psychol. 2020;11(July).

23. Ponizovskiy V, Grigoryan L, Kühnen U, 
Boehnke K. Social construction of the valuebehavior relation. Front Psychol. 2019;10(APR):1-12.

24. Wood C, Conner M, Miles E, Sandberg T, Taylor N, Godin G, et al. The Impact of Asking Intention or Self-Prediction Questions on Subsequent Behavior: A Meta-Analysis. Personal Soc Psychol Rev. 2016;20(3):24568.

25. Fischer R, Karl JA. Predicting Behavioral Intentions to Prevent or Mitigate COVID-19: A Cross-Cultural Meta-Analysis of Attitudes, Norms, and Perceived Behavioral Control Effects. Soc Psychol Personal Sci. 2021;

26. Marcinkowski T, Reid A. Reviews of research on the attitude-behavior relationship and their implications for future environmental education research. Environ Educ Res [Internet]. 2019;25(4):459-71. Available from: https://doi.org/10.1080/13504622.2019.16342 37

27. Xu X, Li H, Shan S. Understanding the health behavior decision-making process with situational theory of problem solving in online health communities: The effects of health beliefs, message source credibility, and communication behaviors on health behavioral intention. Int $\mathrm{J}$ Environ Res Public Health. 2021;18(9).

28. Bramantoro $T$, Basiroh $E$, Berniyanti $T$,
Setijanto RD, Irmalia WR. Intention and oral health behavior perspective of islamic traditional boarding school students based on theory of planned behavior. Pesqui Bras Odontopediatria Clin Integr. 2020;20:1-8.

29. Armoon B, Yazdanian M, Higgs P, Nasab HS. Effect of a hospital-based oral healtheducation program on Iranian staff: evaluating a theory-driven intervention. BMC Med Educ. 2021:21(1):1-10.

30. Putri KY, Airlangga U. Gambaran Theory of Planned Behavior ( Tpb ) Pada Perilaku Sarapan Pagi Mahasiswa Alih Jenis Fakultas Ekonomi Dan Theory of Planned Behavior ( $\mathrm{Tpb}$ ) on Breakfast Behavior At the Student Over the Type of Faculty of Economics and Business. Promosi Kesehat. 2018;6:80-92.

31. Serdiuk L, Danyliuk I, Chaika G. Personal Autonomy As a Key Factor of Human SelfDetermination. Soc Welf Interdiscip Approach. 2018;1(8):85.

32. Kana IM., Nayoan CR, Limbu R. Gambaran Perilaku Pencegahan Hiv Dan Aids Pada Lelaki Suka Lelaki (Lsl) Di Kota Kupang Tahun 2014. Unnes J Public Heal. 2016;5(3):252.

33. Syam AZ, Suriah S, Abdullah MT. Perilaku Pengambilan Keputusan Oleh lbu Hamil Dalam Pencarian Pelayanan Kesehatan Di Wilayah Pesisir Kota Palu. J Kesehat Masy Marit. 2020;2(1). 